\title{
MRS-I Features Building Materials at 10th Annual General Meeting
}

The three-day 10th Annual General Meeting of the Materials Research Society of India (MRS-I), organized by Regional Research Laboratory (RRL), was held during February 8-10 at Ravindra Bhawan, a central place of Bhopal. The traditional structure of the Meeting included honor lectures, MRSI-ICSC (International Conference on Superconductivity) lectures, medal award lectures, invited lectures on the theme seminar, poster sessions, and a council meeting. To mark the 10th anniversary, the exhibit on developments in materials science and technology presented an NCSTC (National Committee on Science and Technology Communication) exhibition on the progress of modern India. Artisans from rural and tribal areas of Madhya Pradesh (M.P.) and Rajasthan demonstrated traditional crafts in metals, clays, and natural fibers.

In his inauguration speech, C.N.R. Rao (JNCASR), Founder President of MRS-I, said that materials research has a tremendous future in India. He said that strides in the field of information technology were largely possible through materials research. He also said that the next century would witness a further growth in population, causing housing problems, and that more building materials would be required. He lauded M.P. for being the only state in the country that is carrying out technology missions that have achieved wide acclaims. For example, the M.P. government initiated steps for application of science and technology for rural areas, and set up a science and technology planning committee.

R. Chidambaram (Atomic Energy Commission), MRS-I president, delivered the customary presidential address. He said that materials research had played a vital role in last year's nuclear experiments. $\mathrm{He}$ stressed the need to specifically focus on the contributions made in India. He also said a criteria should be adopted to give credit to people doing materials research.

T.C. Rao, director at RRL, welcomed dignitaries and delegates. He said that a caring and supportive patronage was provided by Honorable Chief Minister of M.P. Shri Digvijay Singh along with Shri K.K. Gupta, Honorable Minister of Higher Education, Mineral Resources, and Man Power Planning. He also acknowledged M.P. as the heartland state of India, resplendent with natural resources: It has immense mineral, forest, water, and agrobased resources which provide exciting opportunities for carrying out high scientific and technological studies and interventions.

S.N. Dwivedi, Director General of M.P. Council of Science and Technology, deliv-

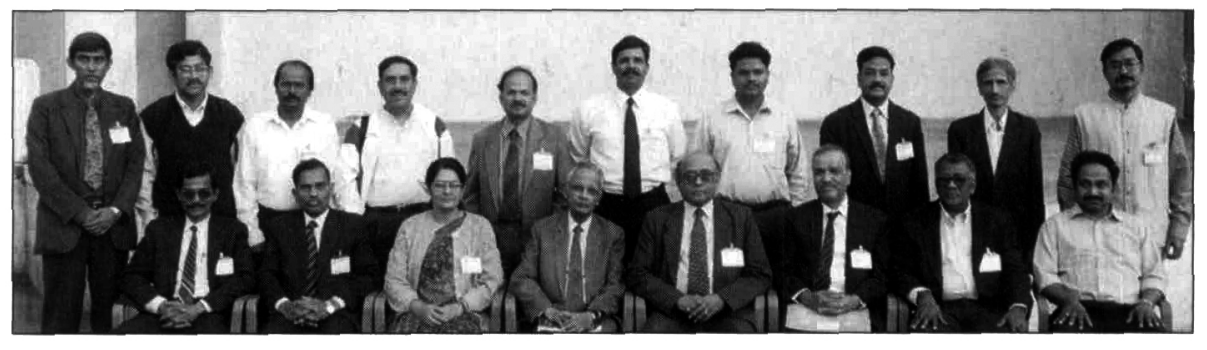

Honor Lecturers and Medal recipients at the 10th Annual General Meeting of the Materials Research Society of India held in February. (Sitting from left to right): S.K. Ray, A. Venkateswararao, S. Ray, C.V. Sundaram, R. Chidambaram, S.K. Joshi, T.S. Radhakrishnan, and T. Rajasekharan. (Standing from left to right): M.K. Banerjee, S. Bhattacharya, K. Sreenivasan, S.M. Sharma, G.V.S. Sastry, R. Balasubramaniam, G.U. Kulkarni, N. Chand, Y.R. Mahajan, and S. Natarajan.

ered a welcome address on behalf of the state government of M.P. The chair of the MRS-I Bhopal Chapter, Shri M.S. Virdi, proposed a vote of thanks. Shri P.D. Ekbote, vice chair of the MRS-I Bhopal Chapter, conducted the inaugural session.

That evening, Honorable Chief Minister Singh hosted a dinner in honor of the dignitaries and delegates. He called for a progressive role of science and technology in regional development, and complimented MRS-I for organizing the Meeting in Bhopal. He was accompanied by some cabinet colleagues and senior officials of M.P. state government. Honorable Minister Gupta hosted a lunch the next day at which he discussed mineral resources management in M.P. and welcomed modern scientists and technological support to this core sector.

The Meeting presented seven technical sessions and a theme seminar on building materials, featuring six invited lectures and five contributed lectures. C.V. Sundaram (National Institute of Advanced Sciences [NIAS] Bangalore), S.K. Joshi (National Physical Laboratory and MRS-I past president), and P. Ramachandra Rao (National Metallurgical Laboratory, Jamshedpur) delivered honor lectures. Joshi received the Senior MRSI-ICSC award and T.S. Radhakrishnan (Indira Gandhi Centre for Atomic Research [IGCAR], Kalpakkam) and Y.R. Mahajan (International Advanced Research Centre for Powder Metallurgy and New Materials [ARC-I], Hyderabad) received annual MRSI-ICSC awards. Thirteen MRS-I medal lectures were presented in four technical sessions.

Three poster sessions representing 11 subject groups were held, presenting 150 papers. During the closing ceremony on February 10, S.V. Subramanyam (Indian Institute of Science in Bangalore and General Secretary of MRS-I) announced award recipients of the poster sessions: S.P. Narayan (RRL), K. Basu (RRL), and B.N. Das (RRL, U.S. Naval Research Laboratory), "Development of Nanocrystalline Nd-Fe-B Magnets and Their Characterization," and Anish Kumar, B.K. Choudhary, K. Laha, T. Jayakumar, K. Bhanu Shankarao Rao, and Baldev Raj, all from IGCAR, Kalpakkam, "Microstructural Characterization of $9 \mathrm{Cr}-1$ Mo Ferritic Steel by Ultrasonic."

The MRS-I Council Meeting was held on February 8 at the Technical Teachers' Training Institute (TTTI), Bhopal. Policy matters regarding strengthening subject groups, globalization, effective dissemination of information to MRS-I members, and efforts made by members and chapters of MRS-I to raise resources were discussed at length. A subject group meeting on building materials was held the next day at TTTI at which scientists of the Council of Scientific and Industrial Research (CSIR) laboratories, including RRL, Central Building Research Institute (CBRI) in Roorkee, Structural Engineering Research Centre (SERC) in Chennai, and personnel from other organizations including industries and government agencies, participated. In carrying out major initiatives for evolving building plans for rural India, the Building Materials group must also consider a large amount of fly ash that has to be used in construction activities and development of buildings protected from natural disasters like floods and earthquakes. The group suggests that a national effort be made through MRS-I.

The Council announced that the next Annual General Meeting will be held at Baroda, under joint auspices of Sardar Patel University, Vallabh Vidyanagar, and the Indian Petrochemical Corporation (IICL).

S.V. SUBRAMANYAM General Secretary, MRS-I 